\title{
INDEPENDENSI, KOMITMEN ORGANISASI, GAYA KEPEMIMPINAN, DAN PEMAHAMAN GOOD GOVERNACE TERHADAP KINERJA AUDITOR
}

\author{
Oleh \\ Sriyanto \\ Dista Amalia Arifah \\ Email : distasmalia Qgrmatil.com \\ Universitas Istam Sultan Agung \\ Riwayat Artikel: dikirim Oktober 2018, diterima September 2018, diterbitkan September 2018
}

Abtract

This study aims to independence, organization comitmen, leadership, and corporate governance undserstanding on public sector auditor performance. Research used internal government auditor which belong to BPKP representation of Jawa Tengah province as population. Sample used comvenience sampling method. From 60 questionare, it was only 42 return questionare. The statistic method used to test on the research hypothesis is multiple regression.

The result of these study show that: organization comitmen. leadership, and corporate governance undserstanding had effect on public sector auditor performance

Keywords : atditor, independence, organization comitmen, leadership, 


\section{PENDAHULUAN}

\section{Latar Belakang}

Laporan Keuangan yang baik adalah laporan keuangan yang sesuai dan memenuhi kebutuhan pemakainya, dalam hal pengambilan keputusan terkait dengan informasi kinerja suatu entitas. Selain itu, keandalan informasi yang disajikan juga merupakan salah satu faktor yang mempengaruhi keputusan para pemakai laporan keuangan. Keandalan laporan keuangan dapat dicapai dengan adanya audit pada laporan keuangan, baik untuk entitas swasta maupun sektor publik.

Berbeda dengan entitas swasta, pada entitas sektor publik proses audit dilakukan oleh auditor pemerintah, baik di tingkat daerah (BPKP) maupun pusat (BPK). Dalam menjalankan pemeriksaan, auditor pemerintah menggunakan norma pemeriksaan yang sudah baku, sesuai dengan aturan pemerintah yang ada. Pengukuran kinerja auditor pemerintah berbeda dengan entitas proses auditnya meskipun Auditor sektor publik dilakukan pada oraganisasi pemerintahan yang bersifat nirlaba dengan pengelolaan aset kekayaan negara untuk kepentingan bersama. Dalam rangka mewujudkan good governance pada entitas publik perlu dilakukan reformasi dalam segala aspek pengelolaan keuangan. Melalui reformasi audit ini diharapkan kegiatan audit dapat berjalan lebih maksimal, sehingga dapat mengurangi terjadinya kesalahan prosedur dan tindak pidana yang sering dilakukan auditee, yang berdampak pada kerugian negara. Pemerintahan yang bersih atau good governance ditandai dengan tiga pilar utama yaitu partisipasi, transparasi dan akuntabilitas yang merupakan elemen dasar yang saling berkaitan (Prajogo, 2001).

Profesi auditor merupakan profesi kepercayaan masyarakat karena memiliki peranan penting dalam melakukan audit laporan keuangan sebuah organisasi. Dari profesi auditor, masyarakat mengharapkan penilaian yang bebas dan tidak memihak terhadap informasi yang disajikan oleh manajemen perusahaan dalam laporan keuangan (Mulyadi dan Puradireja, 1998 dalam Kharismatuti, 2012). Profesi auditor hartanumunoiawah untuk menaikkan tingkat keandalan laporan keuangan perusahaan, sehingga informasi tersebut dapat dijadikan sebagai dasar pengambilan keputusan yang tepat. Agar seorang auditor dapat melakukan tugasnya dengan baik auditor harus bersikap profesionalisme.

Independensi merupakan salah satu aspek penting bagi profesionalisme akuntan khususnya dalam membentuk integritas pribadi yang tinggi. Independensi dapat juga diartikan adanya kejujuran dalam diri auditor dalam mempertimbangkan fakta dan adanya pertimbangan yang obyektif tidak memihak dalam diri auditor dalam merumuskan dan menyatakan pendapatnya (Mulyadi, 2002). Seorang auditor yang memiliki indenpendensi tinggi, kinerjanya akan menjadi lebih baik, sehingga lebih profesional dalam tugasnya (Chirtiawan, 2002 dalam Alim et al., 2007).

Profesionalisme sendiri harus ditunjang dengan komitmen seseorang terhadap organisasinya. Adanya suatu komitmen organisasi yang tinggi dapat menjadi suatu dorongan bagi seseorang auditor untuk bekerja lebih baik dan lebih profesinal. Persepsi auditor terhadap komitmen mereka pada organisasi tersebut dan kepedulian organisasi terhadap kesejahteraan mereka, yang dapat menimbulkan komitmen auditor untuk tetap setia bekerja pada organisasi tersebut (Shore and Tetrik, 1990 dalam Mallisa, 2009). Yousef (2000) dalam Trisnaningsih (2007) menyatakan bahwa komitmen organisasi memediasi hubungan antara perilaku kepemimpinan dengan kinerja, di mana anggota organisasi lebih puas dengan pekerjaannya dan kinerja mereha menjad lebih tinggi.

Gaya kepemimpinan (leadership style) merupakan cara pimpinan untuk mempengaruhi orang lain atau bawahannya sedemikian rupa sehingga orang tersebut mau melakukan kehendak pimpinan untuk mencapai tujuan organisasi meskipun secara pribadi hal tersebut murgkin tidak disenangi. Menurut Alberto at al., (2005) dalam Trisnaningsih (2007) kepemimpinan berpengaruh positif kuat terhadap kinerja. Temuan ini memberikan sinyal bahwa gaya kepemimpinan seorang pemimpin sanga berpengaruh terhadap kinerja bawahannya, 
di samping itu untuk mendapatkan kinerja yang baik diperlukan juga adanya pemberian pembelajaran terhadap bawahannya.

Selain beberapa faktor diatas, auditor juga perlu memahami tentang good governance. Secara ideal dalam menjalankan profesinya, seorang auditor hendaknya memperhatikan prinsip dasar good governance. Sunarsip (2001) dalam Ramadhan (2011) mengemukakan bahwa terjadinya krisis ekonomi di Indonesia disebabkan oleh tata kelola yang buruk (bad governance) pada sebagian besar pelaku ekonomi (publik dan swasta). Ramadhan (2011) juga menyatakan bahwa peran profesi auditor selama ini masih belum optimal dalam mewujudkan good governance. Oleh sebab itu tuntutan terhadap terwujudnya good governance (tata kelola yang baik) sangat diperlukan. Aturan yang mengacu prinsip good governance tidak hanya akan mencegah skandal tetapi juga bisa mendongkrak kinerja korporat (Samianto, 2004 dalam Trisnaningsih, 2007).

Beberapa penelitian mengenai pengaruh independensi, komitmen organisasi, gaya kepemimpinan, dan pemahaman good governance dengan kinerja auditor menunjukkan hasil yang berbeda-beda. Hasil penelitian Trisnaningsih (2007) menemukan bahwa ada hubungan negatif antara pemahaman good governance dan budaya organisasi dengan kinerja auditor sedangkan gaya kepemimpinan berpengaruh positif dengan kinerja auditor. Penelitian tersebut didukung oleh penelitian Ramadhan (2011) yang menemukan bahwa terdapat hubungan negatif antara good governance dengan kinerja auditor. Sebaliknya, penelitian yang dilakuan oleh Wati et al. (2010) menemukan hubungan positif antara independensi, gaya kepemimpinan, komitmen organisasi dan pemahaman good governance terhadap kinerja auditor. Penelitian Wati et al., didukung oleh Lawalata et al., (2008) yang menemukan hubungan positif antara independensi auditor, komitmen organisasi, gaya kepemimpinan dan budaya organisasi terhadap kinerja auditor.

Terkait dengan beragamnya hasil penelitian yang ada, maka peneliti tertarik untuk melakukan penelitian sejenis dengan mengacu pada penelitian Wati et al., (2010). Namun terdapat perbedaan antara penelitian ini dengan penelitian sebelumnya yaitu pada survei penelitiannya. Penelitian sebelumnya berada di Bengkulu, sedangkan penelitian saat ini ingin memperluas objek penelitian dengan melibatkan BPKP (Badan Pemerikasa Keuangan Pemerintah) yang merupakan auditor internal pemerintah perwakilan Jawa Tengah.

Berdasarkan latar belakang yang diuraikan diatas, penelitian ini mengulas tentang factor-faktor yang mempengaruhi kinerja auditor sektor publik. Hal ini dilakukan karena auditor sangat berperan dalam sistem pengendalian perusahaan yang pada akhirnya akan mempengaruhi kinerja dari perusahaan.

\section{KERANGKA TEORITIS DAN PENGEMBANGAN HIPOTESIS \\ Teori Agensi (Agency Theory)}

Teori Keagenan (Agency Theory) merupkan konsep yang menjelaskan hubungan kontraktual antara principal dan agensi. Pihak principal adalah pihak yang memberikan mandat kepada pihak lain yaitu agen untuk melakukan semua kegiatan atas nama principal dalam kapasitasnya sebagai pengambilan keputusan. Principal ingin mengetahui segala informasi termasuk aktivitas manajemen, yang terkait dengan investasi atau dananya dalam porganisasi. Hal ini dilakukan dengan meminta laporan pertanggungjawaban pada agen (manajemen). Berdasarkan laporan tersebut principal menilai kinerja manajemen, tetapi yang acapkali terjadi adalah kecenderungan manajemen untuk melakukan tindakan yang membuat laporannya kelihatan baik, sehingga kinerjanya dianggap baik (Indah, 2010). Untuk mengurangi atau meminimalkan kecurangan yang dilakukan oleh manajemen dan membuat laporan keuangan yang dibuat manajemen lebih reliable (dapat dipercaya) diperlukan pengujian.

Berdasarkan hal tersebut dibutulkkan pihak ketiga yang independen sebagai mediator pada hubungan antara principal dengan agen dalam hal ini adalah auditor intemal yang independen (Indah, 2010). Pihak ketiga ini berfungsi memonitor 
perilaku agen dan memastikan bahwa agen bertindak sesuai dengan kepentingan principal. Tugas auditor disisni untuk menjembatani kepentingan pihak principal dengan pihak agen dalam mengelola keuangan seuatu organisasi.

Pengembangan Hipotesis

Pengaruh Independensi Terhadap Kineria Auditor

Independensi merupakan aspek penting bagi profesionalisme akuntan khususnya dalam membentuk integritas pribadi yang tinggi. Hal ini disebabkan karena pelayanan jasa akuntan sangat dipengaruhi oleh kepercayaan klien maupun publik secara luas dengan berbagai macam kepentingan yang berbeda. Klien dapat mempunyai kepentingan yang berbeda, bahkan mungkin bertentangan dengan kepentingan para pemakai laporan keuangan. Kepentingan pemakai laporan keuangan yang satu mungkin berbeda dengan pemakai lainnya.

Oleh karena itu dalam memberikan pendapat mengenai kewajaran laporan keuangan yang diperiksa, akuntan publik harus bersikap independen terhadap kepentingan klien, para pemakai laporan keuangan, maupun terhadap kepentingan akuntan publik itu sendiri. Auditor yang menegakkan independensinya, tidak akan terpengaruh dan tidak dipengaruhi oleh berbagai kekuatan yang berasal dari luar diri auditor dalam mempertimbangkan fakta yang dijumpainya dalam pemeriksaan, sehingga seorang auditor yang memiliki indenpendensi yang tinggi maka kinerjanya akan menjadi lebih baik.

Pada penelitian yang dilakukan Trisnaningsah (2007) membuktikan bahwa independensi auditor berpengaruh terhadap kinerja auditor. Sama halnya dengan penelitian yang dilakukan oleh Lawalata ef al., (2008) bahwa terdapat pengaruh positif independensi auditor terhadap kinerja auditor. Dari uraian diatas dapat dirumuskan hipotesis sebagai berikut:

$\mathrm{H}_{1}$ : Independensi berpengaruh positif

terhadap kinerja auditor

Pengaruh Komitmen Organisasi

Terhadap Kineria Auditor

Komitmen organisasi cenderung didefinisikan sebagai suatu perpaduan antara sikap dan perilaku. Oleh karena itu komitmen organisasi akan menimbulkan rasa memiliki (sense of belonging) bagi auditor terhadap organisasi. Jika seorang karyawan merasa jiwanya terikat dengan nilai-nilai organisasional yang ada maka dia akan merasa senang dalam bekerja, sehingga kinerjanya dapat terus meningkat. Wati et al., (2010) mengungkapkan bahwa keberhasilan dan kinerja seseorang dalam suatu bidang pekerjaan sangat ditentukan oleh profesionalisme terhadap bidang yang ditekuninya.

Komitmen yang tepat akan memberikan motivasi yang tinggi dan memberikan dampak yang positif terhadap kinerja suatu pekerjaan. Jika auditor merasa jiwanya terikat dengan nilai-nilai organisasional yang ada maka dia akan merasa senang dalam bekerja, sehingga kinerjanya dapat meningkat. Hal ini berarti bahwa semakin tinggi komitmen seorang auditor pemerintah terhadap organisasi, maka kinerja auditor pemerintah akan semakin baik.

Hasil studi Ketchand dan Strawser, 2001; Siders et al., 2001; Fernando et al., (2005) dalam Marganingsih dan Martini (2009) memberikan kesimpulan yang sama bahwa komitmen organisasi mempunyai pengarub positif terhadap kinerja. Hasil penelitian tersebut didukung oleh Trisnaningsih (2007), Marganingsih dan Martini (2009), dan Wibowo (2009) dalam Wati et al., (2010) yang menyatakan bahwa komitmen organisasi mempengaruhi secara positif kinerja auditor. Berdasarkan uraian di atas dapat dirumuskan hipotesis penelitian sebagai berikut:

$\mathrm{H}_{2}$ : Komitmen organisasi berpengaruh positif terhadap kinerja auditor.

Pengaruh Gaya Kepemimpinan Terhadap Kineria Auditor

Gaya kepemimpinan merupakan norma perilaku yang digunakan seoran manajer pada saat ia mempengaruh perilaku bawahannya. Gaya kepemimpinat dapat mempengaruhi kreativitas kinerj auditor dalam melaksanakan tugasny sebagai anggota organisasi. Semaki cakapnya seorang pemimpin dalan mengatur/mempengaruhi bawahanny maka bawahannya akan termotivasi da bersemangat untuk bekerja, sehingg kualitas kerja (kinerja) bawahannya aka semakin baik.

Penelitian yang dilakukan ole Goleman (2004) dalam Wati et al., (2010 
menyatakan bahwa gaya kepemimpinan manajer dapat mempengaruhi produktifitas karyawan (kinerja karyawan), hasil penelitian ini selaras dengan temuan Lawalata et al., (2008) menyatakan bahwa kepemimpinan berpengaruh positif kuat terhadap kinerja auditor. Dari uraian diatas dapat dirumuskan hipotesis penelitian sebagai berikut:

$\mathrm{H}_{3}$ : Gaya kepemimpinan berpengaruh positif terhadap kinerja auditor. Pengaruh Pemahaman Good Governance Terhadap Kineria Auditor. Good governance merupakan tata kelola yang baik pada suatu usaha yang dilandasi oleh etika profesional dalam berusaha atau berkarya. Good governance merupakan prinsip pengelolaan perusahaan yang bertujuan untuk mendorong kinerja perusahaan, serta memberikan nilai ekonomis bagi pemegang saham maupun masyarakat secara umum. Seorang akuntan yang memahami good governance secara benar maka akan mempengaruhi perilaku profesional akuntan dalam berkarya dengan orientasi pada kinerja yang tinggi untuk mencapai tujuan akhir sebagaimana diharapkan oleh berbagai pihak (Trisnaningsih, 2007).

Hasil penelitian Darwati et al., (2004) dalam Wati et al., (2010) membuktikan bahwa corperate governance berhubungan positif dengan kinerja perusahaan. Hasil penelitian Wibowo (2009) dalam Wati et al., (2010) juga berhasil membuktikan pemahaman good governance berpengaruh positif terhadap kinerja auditor.

Berdasarkan uraian di atas dapat disimpulkan bahwa seorang auditor pemerintah yang memahami good governance dengan baik maka dia akan bekerja sesuai dengan aturan yang ada, sehingga kinerja auditor pemerintah akan menjadi lebih baik. Dengan demikian dapat dirumuskan hipotesis sebagai berikut :

\section{$\mathrm{H}_{4}$ : Pemahaman good governance}

berpengaruh positif terhadap kinerja auditor.

\section{METODE PENELITIAN}

Populasi dan Sampel

Populasi dalam penelitian ini adalah auditor sektor publik, sedangkan yang dijadikan sampel adalah auditor yang bekerja di Kantor Badan Pengawas Keuangan Pemerintah (BPKP) perwakilan
Provinsi Jawa Tengah. Dalam penelitian ini, peneliti menggunakan metode pemilihan sampel nonprobalitas atau pemilihan sampel tidak acak yaitu pemilihan sampel berdasarkan kemudahan (Convenience Sampling). Indriantoro dan Supomo (2009) metode convenience sampling adalah metode yang memilih sampel dari elemen populasi ( orang atau kejadian) yang datanya mudah diperoleh peneliti. Kuesioner dalam penelitian ini diukur dengan skala likert.

\section{Defínisi Oprasional Variabel}

1. Variabel Independen

Independensi

Independensi dalam penelitian ini digunakan sebagai variabel independen. Independensi dalam penelitian ini menunjukkan kebebasan posisi auditor baik sikap maupun penampilan dalam hubungannya dengan klien yang terkait dengan tugas audit yang dilaksanakan. Sikap dimana tidak bisa terpengaruh dan dipengaruhi.

Independensi dalam penelitian ini mengacu pada lima instrumen pertanyaan yaitu (1) pengungkapan kecurangan klien, (2) besarnya fee audit, (3) pemberian fasilitas dari klien, (4) penggantian auditor, (5) penggunaan jasa non audit. Skala pengukuran yang digunakan adalah skala Likert 5 poin. Angka 5 berarti Sangat Setuju, angka 4 berarti Setuju, angka 3 berarti Netral, angka 2 berarti Tidak Setuju, dan angka I berarti Sangat Tidak Setuju.

\section{Komitmen Organisasi}

Komitmen organisasi dalam penelitian ini digunakan sebagai variabel independen. Komitmen organisasi dalam penelitian mengacu pada tingkat keterlibatan auditor dengan organisasinya. Keterlibatan kerja yang tinggi berarti pemihakan seseorang pada pekerjaannya yang khusus, komitmen pada organisasi yang tinggi berarti pemihakan pada organisasi yang mempekerjakannya.

Komitmen organisasi diukur dengan menggunakan instrumen yang dikembangkan oleh Meyer dan Allen (1984) dalam Rohman (2008). Instrumen ini terdiri dari dua belas (12) item pertanyaan. Skala pengukuran yang digunakan adalah skala Likert 5 poin. Angka 5 berarti Sangat Setuju, angka 4 berarti Setuju, angka 3 berarti Netral, 
angka 2 berarti Tidak Setuju dan angka 1 berarti Sangat Tidak Setuju.

\section{Gaya Kepemimpinan}

Gaya kepemimpinan dalam penelitian ini digunakan sebagai variabel independen. Gaya kepemimpinan dalam penelitian ini mengacu pada suatu cara yang digunakan oleh seorang pemimpin untuk mempengaruhi dan mengatur serta mengkoordinasikan bawahan dalam rangka pencapaian tujuan organisasi yang efektif. Gaya kepemimpinan diukur dengan menggunakan instrumen yang dikembangkan oleh Behling dan Mcfellen (1996) dalam Baihaqi (2010). Instrumen tersebut diukur dengan dua indikator sebagai berikut:

1. Kuesioner Kepercayaan Pengikut ( Follower Belief Questionnaire)

(1) Inspirasi

(2) Kekaguman

(3) Pemberdayaaan

2. Kuesioner Atribut Perilaku Pemimpin ( Attributes of Leader Behavior Questionnaire)

(1) Menunjukkan empati

(2) Menjelaskan misi dengan menarik

(3) Menunjukkan keyakinan

(4) meningkatkan image

(5) memberikan peluang untuk sukses Skala pengukuran yang digunakan adalah skala Likert 5 poin. Angka 5 berarti Sangat Setuju, angka 4 berarti Setuju, angka 3 berarti Netral, angka 2 berarti Tidak Setuju, dan angka 1 berarti Sangat Tidak Setuju.

\section{Pemahaman Good Governance}

Pemahaman good governance dalam penelitian ini digunakan sebagai variabel independen. Pemahaman good governance dalam penelitian ini mengacu pada seberapa jauh pemahaman atas konsep tata kelola pemerintahan atau organisasi yang baik oleh para auditor.

Pemahaman good governance diukur dengan mengadopsi instrumen yang dikembangkan oleh Indonesian Institute of Corporate Governance yang meliputi (1) keadilan, yaitu kemampuan yang cukup untuk melaksanakan kebijakandan fungsifungsi pemerintah, termasuk sistim administrasi publik yang efektif danresponsif, (2) tramparansi, (3) akuntabilitas, (4) pertanggungjawaban. Skala pengukuran yang digunakan adalah skala Likert 5 poin. Angka 5 berarti Sang Setuju, angka 4 berarti Setuju, angka berarti Netral, angka 2 berarti Tida Setuju, dan angka 1 berarti Sangat Tida Setuju.

\section{Variabel Dependen}

Kinerja Auditor

Kinerja auditor dalam penelitia ini digunakan sebagai variabel depende Kinerja Auditor dalam penelitian ini adal hasil kerja secara kualitas dan kuantit yang dicapai auditor dalam melaksanak tugas sesuai dengan tanggung jawab yar diberikan kepadanya.

Kinerja auditor diukur deng mengembangkan instrumen yar diciptakan oleh Larkin (1990) dala Sapariah (2011) yaitu (1) kemampuan, ( Komitmen profesi, (3) motivasi, kepuasan kerja, (5) tingkat pendidikan, d (6) faktor usia dan pengalaman. Ski pengukuran yang digunakan adalah sk Likert 5 poin. Angka 5 berarti San Setuju, angka 4 berarti Setuju, angka berarti Netral, angka 2 berarti Tid Setuju, dan angka 1 berarti Sangat Tid Setuju.

Teknik Analisis

Kuesioner yang masuk diu kualitas datanya dengan uji validitas da reliabilitas. Kemudian dilakukan normalitas dan uji asumsi klasik yar meliputi multikolinearitas da heterokedastisitas. Teknik analisis yar digunakan untuk menguji hipotesis adal analisis regresi berganda.

\section{HASIL DAN PEMBAHASAN Hasil Analisis \\ Data yang kembali 40 kuesioner D hasil uji kualitas data, uji normalitas uji asumsi klasik, didapatkan hasil bah data dan variabel yang ada lay terdistribusi normal dan lolos uji asu klasik. \\ $\frac{\text { Analisis Regresi Linier Berganda }}{\text { Perhitungan regresi }}$} berganda antara independensi, komitr organisasi, gaya kepemimpinan pemahaman good governance terha kinerja auditor dengan dibantu prog SPSS dalam proses penghitungannya d: diperoleh hasil sebagai berikut:

Tabel 1 


\section{Coefficients}

\begin{tabular}{|c|c|c|c|c|c|c|}
\hline \multirow{2}{*}{\multicolumn{2}{|c|}{ Model }} & \multicolumn{2}{|c|}{$\begin{array}{c}\text { Unstandardized } \\
\text { Coefficients }\end{array}$} & \multirow{2}{*}{$\begin{array}{c}\begin{array}{c}\text { Standardized } \\
\text { Coefficients }\end{array} \\
\text { Beta }\end{array}$} & \multirow[b]{2}{*}{$\mathrm{t}$} & \multirow[b]{2}{*}{ Sig. } \\
\hline & & $\mathrm{B}$ & Std. Error & & & \\
\hline \multirow[t]{5}{*}{1} & (Constant) & 16,277 & 3,068 & & 5,306 &, 000 \\
\hline & Independensi &, 064 & .107 &, 068 & .596 &, 555 \\
\hline & Komiten Organisasi & .287 & .059 & .459 & 4,851 & .000 \\
\hline & Gaya Kepemimpinan & .465 & .123 &, 366 & 3,787 &, 001 \\
\hline & Good Goverance & .285 & .103 & .258 & 2,768 &, 009 \\
\hline
\end{tabular}

a. Dependent Variable: Kinerja Auditor

Sumber : data primer yang diolah

$$
\begin{aligned}
\mathrm{YK}= & 16,277+0,064 \mathrm{XInd}+0,287 \mathrm{Xko}+ \\
& 0,465 \mathrm{Xgk}+0,285 \mathrm{Xpgg}+\mathrm{e} \\
& \text { Hasil persamaan regresi linier }
\end{aligned}
$$
berganda tersebut di atas memberikan pengertian bahwa :

a. $b_{1}$ (nilai koefisien regresi independensi) bernilai positif, mempunyai arti apabila mengetahui apakah independensi, komitmen organisasi, gaya kepemimpinan dan pemahaman good governance secara bersama-sama berpengaruh terhadap kinerja auditor yang diambil auditor. Hasil pengujian ini dapat dilihat pada tabel 2

Tabel 2

Hasil Uji F

ANOVA

\begin{tabular}{|ll|r|r|r|r|r|}
\hline Model & $\begin{array}{r}\text { Sum of } \\
\text { Squares }\end{array}$ & df & Mean Square & F & Sig. \\
\hline 1 & Regression & 1277,474 & 4 & 319,369 & 34,657 &, $000^{\text {a }}$ \\
& Residual & 322,526 & 35 & 9,215 & & \\
& Total & 1600,000 & 39 & & & \\
\hline
\end{tabular}

a. Predictors: (Constant), Good Goverance, Gaya Kepemimpinan, Komiten Organisasi, Independensi

b. Dependent Variable: Kinerja Auditor

independensi semakin meningkat, maka kinerja auditor semakin meningkat,

b. $b_{2}$ (nilai koefisien regresi komitmen organisasi) bernilai positif, mempunyai arti apabila komitmen organisasi semakin meningkat, maka kinerja auditor semakin meningkat.

c. b, (nilai koefisien regresi gaya kepemimpinan) bernilai positif, mempunyai arti apabila gaya kepemimpinan semakin meningkat, maka kinerja semakin meningkat.

d. $b_{i}$ (nilai koefisien regresi pemahaman good goverance) bernilai positif, mempunyai arti apabila pemahaman good governance meningkat, maka kinerja auditor semakin meningkat,

Uji F
Sumber : Data primer yang diolah Nilai signifikasi $\mathrm{F}$ sebesar 0,000 $<0,05$, dengan demikian persamaan semua variabel independensi, komitmen organisasi, gaya kepemimpinan dan pemahaman good governance secara bersama-sama berpengaruh terhadap kinerja auditor yang diambil auditor.

Uji t (Uji Hipotesis)

Berdasarkan perhitungan uji regresi berganda yang tercantum pada table 1, maka hasilnya memberikan pengertian bahwa :

a. Pengaruh Independensi terhadap Kinerja auditor

Hasil perhitungan tabel 11 , diperoleh nilai signifikasi untuk independensi adalah $\alpha=0,555>0,05$ menandakan bahwa independensi tidak 
mempunyai pengaruh terhadap kinerja auditor. Dengan demikian dapat disimpulkan bahwa $\mathrm{H} 1$ ditolak, sehingga hipotesis yang menyatakan dugaan adanya pengaruh positif independensi terhadap kinerja auditor yang diambil auditor ditolak.

b. Pengaruh Komitmen Organisasi terhadap Kinerja auditor Hasil perhitungan tabel 11 , diperoleh nilai signifikasi untuk komitmen organisasi adalah $\alpha=0,000<0,05$ menandakan bahwa komitmen organisasi mempunyai pengaruh positif terhadap kinerja auditor. Dengan demikian dapat disimpulkan bahwa $\mathrm{H} 2$ diterima, sehingga hipotesis yang menyatakan dugaan adanya pengaruh positif komitmen organisasi terhadap kinerja auditor yang diambil auditor diterima.

c. Pengaruh Gaya Kepemimpinan terhadap Kinerja auditor

Hasil perhitungan tabel 11 , diperoleh nilai signifikasi untuk gaya kepemimpinan adalah $\alpha=0,001<0,05$ menandakan bahwa gaya kepemimpinan mempunyai pengaruh positif terhadap kinerja auditor. Dengan demikian dapat disimpulkan bahwa $\mathrm{H} 3$ diterima, sehingga hipotesis yang menyatakan dugaan adanya pengaruh positif komitmen organisasi terhadap kinerja auditor yang diambil auditor diterima.

d. Pengaruh Pemahaman Good Governance terhadap Kinerja auditor

Hasil perhitungan tabel II, pemahaman good governance adalah $\alpha=$ $0,009<0,05$ menandakan bahwa pemahaman good governance mempunyai pengaruh positif terhadap kinerja auditor. Dengan demikian dapat disimpulkan bahwa $\mathrm{H} 4$ diterima, sehingga hipotesis yang menyatakan dugaan adanya pengaruh positif pemahaman good governance terhadap kinerja auditor yang diambil auditor diterima.

Koefisien Determinasi $\left(\mathrm{R}^{2}\right)$

Persentase variabel dependen (kinerja auditor) dapat dijelaskan oleh variabel independen (independensi, komitmen organisasi, gaya kepemimpinan dan pemahaman good governance) dalam model penelitian ditunjukkan oleh besarnya Koefisien Determinasi. Koefisien Determinasi ini menunjukan seberapa besat pengaruh variabel bebas terhadap variabel dependent atau bebas yang dinyatakan dalam persen $(\%)$.

Tabel 3

Koefisien Determinasi

Model Summary

\begin{tabular}{|r|r|r|r|}
\hline R & R Square & $\begin{array}{r}\text { Adjusted } \\
\text { R Square }\end{array}$ & $\begin{array}{r}\text { Std. Error of } \\
\text { the Estimate }\end{array}$ \\
\hline $.894^{\mathrm{a}}$ & .798 & .775 & 3,036 \\
\hline
\end{tabular}

Predictors: (Constant), Good Goverance, Gaya

Kepemimpinan, Komiten Organisasi, Independensi

Dependent Variable: Kinerja Auditor variabel independensi, komitmen organisasi, gaya kepemimpinan dan pemahaman good governance dapat menjelaskan kinerja auditor yang diambil auditor BPKP RI perwakilan Propinsi Jawa Tengah sebesar 77,50\% sedangkan sisanya diterangkan oleh faktor lain yang tidak diamati dalam penelitian ini, seperti pengetahuan, kompleksitas tugas dan lainlain.

Pembahasan

Pengaruh Independensi Terhadap Kinerja auditor

Independensi tidak mempunyai pengaruh yang signifikan terhadap kinerja auditor, hal ini dibuktikan dengan nilai signifikasi lebih besar dari 0,05. Kondisi ini terjadi karena auditor dalam penelitian ini adalah auditor pemerintah, dimana independensi sudah pasti dimiliki oleh anggota auditor yang sudah diatur dalam Pusdiklatwas BPKP Aturan Perilaku pegawai PP 42/2004 pasal 13. Selain itu sikap independensi juga diatur dalan Kode Etik Akuntan Publik th. 2010 yang disajikan pada paragraf 290 dan 290.8 tentang aturan independensi. Sehingga ada sangsi dari instansi dan dinas apabila terjadi pelanggaran independensi.

Ketidaksignifikanan tersebut juga dapat disebabkan karena pada saat penyusunan program pemeriksaan masih ada intervensi pimpinan untuk menentukan, mengeliminasi atau 
memodifikasi bagian-bagian tertentu yang akan diperiksa serta intervensi atas prosedur-prosedur yang dipilih oleh auditor. Kemudian pada saat pelaksanaan pemeriksaan masih belum bebas dari usaha-usaha manajerial (obyek pemeriksaan) untuk menentukan atau menunjuk kegiatan yang diperiksa, sehingga masih ada auditor yang merasa tidak perlu bekerjasama dengan manajerial. Terakhir, mungkin pada saat penyusunan laporan masih sering menggunakan bahasa atau istilah yang menimbulkan multi tafsir. Hasil ini tidak sesuai dengan Wati et al., (2010), yang menjelaskan bahwa independensi berpengaruh terhadap kinerja auditor, auditor yang menegakkan independensinya, tidak akan terpengaruh dan tidak dipengaruhi oleh berbagai kekuatan yang berasal dari luar diri auditor dalam mempertimbangkan fakta yang dijumpainya dalam pemeriksaan, sehingga seorang auditor yang memiliki independensi yang tinggi, maka kinerjanya akan menjadi lebih baik. Namun, dilain pihak penelitian ini sejalan dengan penelitian yang dilakuakan Sukriah et al., (2009), yang menyatakan independensi tidak berpengaaruh yang signifikan terhadap kinerja auditor yang berdampak pada kualitas auditnya.

\section{Pengaruh Komitmen Organisasi Terhadap Kinerja auditor}

Komitmen orgnisasi mempunyai pengaruh positif yang signifikan terhadap kinerja auditor, hal ini dibuktikan dengan nilai signifikasi lebih kecil dari 0,05 . Kondisi ini terjadi komitmen yang tinggi akan memberikan motivasi yang tinggi dan memberikan dampak yang positif terhadap kinerja suatu pekerjaan. Jika auditor merasa jiwanya terikat dengan nilai-nilai organisasional yang ada, maka dia akan merasa senang dalam bekerja, sehingga kinerjanya dapat meningkat. $\mathrm{Hal}$ ini berarti bahwa semakin tinggi komitmen seorang auditor pemerintah terhadap organisasi, maka kinerja auditor pemerintah akan semakin baik.

Hasil ini sesuai dengan Wati et al., (2010), yang menjelaskan bahwa komitmen organisasi berpengaruh positif terhadap kinerja auditor, auditor yang memiliki komitmen yang tinggi akan bekerja dengan baik-baiknya guna mencapai tujuan perusahaan atau instansi, sehingga kinerjanya akan menjadi lebih baik.

\section{Pengaruh Gaya Kepemimpinan Terhadap Kinerja auditor \\ Gaya kepemimpinan mempunyai} pengaruh positif yang signifikan terhadap kinerja auditor, hal ini dibuktikan dengan nilai signifikasi lebih kecil dari 0,05 . Kondisi ini terjadi karena peranan pemimpin sebagai top manajer, yang berfungsi dalam menggerakkan dan memberdayakan pegawai. Dalam menjalankan roda organisasi manajer memegang peranan yang sangat sentral, pada dirinyalah kebijakan-kebijakan organisasi terlahir. Kepemimpinan meliputi proses mempengaruhi dalam menentukan tujuan organisasi, mempengaruhi perilaku pegawai untuk mencapai tujuan, mempengaruhi untuk memperbaiki kelompok dan budayanya. Kepemimpinan yang baik akan membuat pegawai merasa senang dalam bekerja dan membuat pegawai merasa tenang dalam bekerja, sehingga bisa meningkatkan kinerja pegawai.

Pengetahuan

tentang kepemimpinan telah membuktikan bahwa tipe pemimpin yang demokratislah yang tepat untuk organisasi saat ini, walaupun tidaklah mudah menerapkan tipe kepemimpinan seperti itu. Tetapi, oleh karena tipe ini dianggap paling ideal, maka diharapkan seorang pemimpin berusaha menjadi seorang pemimpin yang demokratis. Variasi yang baik dari tipe-tipe kepemimpin ini adalah tipe kepemimpinan yang demokratis sekaligus kharismatis. Dengan demikian keberadaan pemimpin memiliki legitimasi ganda karena dipilih dan menerpakan pola kepemimpinan yang demokratis sekaligus memiliki kharisma di hadapan masyarakatnya. Tetapi, ada pendapat lain yang menyatakan bahwa seorang pemimpin yang baik adalah pemimpin yang dapat menerapkan berbagai macam tipe memimpin di atas sesuai dengan kondisi dan situasi. Ada kalanya dia bertipe demokratis, tapi dalam kondisi dan situasi yang menuntut dia harus tegas maka sah-sah saja apabila dia bertipe militeristis.

Hasil ini mendukung penelitian Wati et al., (2010) yang menyatakan gaya 
kepemimpinan berpengaruh positif terhadap kinerja auditor, semakin baik gaya kepemimpinan, maka semakin tinggi kinerja karyawan.

\section{Pengaruh Pemahaman Good Governance Terhadap Kinerja auditor} Pemahaman good governance mempunyai pengaruh yang signifikan terhadap kinerja auditor, hal ini dibuktikan dengan nilai signifikasi lebih kecil dari 0,05 . Kondisi ini terjadi karena good governance merupakan tata kelola yang baik pada suatu usaha yang dilandasi oleh etika profesi dalam berusaha atau berkarya. Good governance merupakan prinsip pengelolaan perusahaan yang bertujuan untuk mendorong keinerja perusahaan, serta memberikan nilai ekonomis bagi pemegang saham maupun masyarakat secara umum. Seorang akuntan yang memahami good governance secara benar maka akan mempengaruhi perilaku profesional akuntan dalam berkarya dengan orientasi pada kinerja yang tinggi untuk mencapai tujuan akhir sebagaimana diahrapkan oleh berbagai pihak.

Hasil ini mendukung penelitian Wati et al., (2010) yang menyatakan pemahaman good governance berpengaruh positif terhadap kinerja auditor, karena seorang auditor pemerintah yang memahami good governance dengan baik, maka dia akan bekerja dengan aturan yang ada, sehingga kinerja auditor akan menjadi lebih baik.

\section{KESIMPULAN DAN SARAN \\ Kesimpulan}

Berdasarkan hasil penelitian yang telah dilakukan, maka dapat dibuat kesimpulan sebagai berikut :

1. Independensi tidak mempunyai pengaruh yang signifikan terhadap kinerja auditor, hal ini dibuktikan dengan nilai signifikasi lebih besar dari 0,05 . Kondisi ini terjadi karena auditor dalam penelitian ini adalah auditor pemerintah, dimana independensi sudah pasti dimiliki oleh anggota auditor, sebab ada sangsi dari instansi dan dinas apabila terjadi pelanggaran independensi.

2. Komitmen orgnisasi mempunyai pengaruh positif yang signifikan terhadap kinerja auditor, hal ini dibuktikan dengan nilai signifikasi lebih kecil dari 0,05 . Kondisi ini terjadi komitmen yang tinggi akan memberikan motivasi yang tinggi dan memberikan dampak yang positif terhadap kinerja suatu pekerjaan. Jika auditor merasa jiwanya terikat dengan nilai-nilai organisasional yang ada, maka dia akan merasa senang dalam bekerja, sehingga kinerjanya dapat meningkat. Hal ini berarti bahwa semakin tinggi komitmen seorang auditor pemerintah terhadap organisasi, maka kinerja auditor pemerintah akan semakin baik.

3. Gaya kepemimpinan mempunyai pengaruh positif yang signifikan terhadap kinerja auditor, hal ini dibuktikan dengan nilai signifikasi lebih kecil dari 0,05. Kondisi ini terjadi karena peranan pemimpin sebagai top manajer, yang berfungsi dalam menggerakkan dan memberdayakan pegawai. Dalam menjalankan roda organisasi manajer memegang peranan yang sangat sentral, pada dirinyalah kebijakan-kebijakan organisasi terlahir. Kepemimpinan meliputi proses mempengaruhi dalam menentukan tujuan organisasi, mempengaruhi perilaku pegawai untuk mencapai tujuan, mempengaruhi untuk memperbaiki kelompok dan budayanya. Kepemimpinan yang baik akan membuat pegawai merasa senang dalam bekerja dan membuat pegawai merasa tenang dalam bekerja, sehingga bisa meningkatkan kinerja pegawai.,

4. Pemahaman good governance mempunyai pengaruh yang signifikan terhadap kinerja auditor, hal ini dibuktikan dengan nilai signifikasi lebih kecil dari 0,05 . Kondisi ini terjadi karena good governance merupakan tata kelola yang baik pada suatu usaha yang dilandasi oleh etika profesi dalam berusaha atau berkarya. Seorang akuntan yang memahami good governance secara benar maka akan mempengaruhi perilaku profesional akuntan dalam berkarya dengan orientasi pada kinerja yang tinggi untuk mencapai tujuan akhir sebagaimana diahrapkan oleh berbagai pihak.

\section{Keterbatasan \\ Keterbatasan dalam penelitian in adalah : \\ 1. Tidak mudahnya mendapatkan kembali kuesioner yang telah disebar sesuai dengan yang diharapkan.}


2. Penggunakan metode ini hanya dengan menggunakan metode survey dengan kuesioner, sehingga memungkinkan terjadinya ketidakjujuran dalam menjawab pertanyaan.

3. Dari hasil analisis terdapat kuesioner yang pengisiannya tidak lengkap, sehingga data tidak dapat diolah karena tidak sesuai dengan kriteria.

\section{Saran}

Saran dalam penelitian ini ditujukan kepada Inspektorat dan masyarakat, sebagai berikut :

1. Penggunaan selain metode survey seperti metode interview dapat digunakan untuk mendapatkan komunikasi dua arah dengan subyek dan mendapatkan kejujuran jawaban subyek.

2. Karena dalam penelitian ini terdapat kuesioner yang tidak lengkap pengisiannya, untuk peneliti selanjutnya diharapkan dapat memeriksa terlebih dahulu kelengkapan jawaban pada kuesioner

\section{DAFTAR PUSTAKA}

Alim, M. Nizarul, Trisna Hapsari, dan Liliek Purwanti. 2007. Pengaruh Kompetensi dan Independensi Terhadap Kualitas Audit dengan Etika Auditor Sebagai Variabel Moderasi. SNA X Makasar.

Baihaqi, Muhammad Fauzan. 2010. Pengaruh Gaya kepemimpinan Terhadap Kepuasan Kerja dan Kinerja Dengan Komitmen Organisasi Sebagai Variabel Intervening: Studi pada PT. Yudhistira Ghalia Indonesia Area Yogyakarta, Skripsi SI, Fakultas Ekonomi Universitas Diponegoro. Semarang.

Indah, Siti Nur Mawar. 2010. Pengaruh Kompetensi dan Independensi Auditor Terhadap Kualits Audit (Studi Empiris Pada Auditor K.AP Di Semarang). Skripsi, Fakultas Ekonomi Universitas Diponegoro. Semarang.

Indriantoro, Nur dan Bambang Supomo. 2009. Metodologi Penelitian Bisnis. BPFE. Yogyakarta.

Kharismatuti, Norma. 2012. Pengaruh Kompetensi dan Independensi Terhadap Kualitas Audit Dengan Etika Auditor Scbagai Variabel Moderasi: Studi Empiris pada Internal Auditor BPKP DKI Jakarta. Skripsi SI, Fakultas Ekonomi Universitas Diponegoro. Semarang.
Lawalata, Josina, Darwis Said, dan Mediaty. 2008. Pengaruh Independensi Auditor, Komitmen Organisasi, Gaya Kepemimpinan dan Budaya Organisasi Terhadap Kinerja Auditor: Studi Empiris di Kantor Akuntan Publik di Makasar.

Mallisa, Mika. 2009. Pengaruh Dukungan Organisasi Terhadap Kinerja Internal Auditor pada Perbankan di Makasar. Adiwedia, Edisi Desember 2009.

Marganingsih, Arywarti dan Dwi Martani, 2009. Analisis Variabel Anteseden Perilaku Auditor Internal dan Konsekuensinya Terhadap Kinerja: Studi Empiris pada Auditor di Lingkungan Aparat Pengawasan Intern Pemerintah - Lembaga Pemerintah Non Departemen. SNA XII Palembang. Mulyadi. 2002. Auditing. Edisi Keenam. Penerbit Salemba Empat. Jakarta.

Prajogo. 2001. "Perspektif Pemeriksa terhadap Implementasi Standar Akuntansi Keuangan Sektor Publik". Jurnal Akuntansi dan Keuangan Sektor Publik. Kompartemen Akuntan Sektor Publik Ikatan Akuntan Indonesia. Vol. 02 No. 02. Agustus.

Ramadhan, Syahril, 2011. Analisis Pengaruh Struktur Audit, Konflik Peran, Ketidakjelasan Peran dan Pemahaman Good Governance. Terhadap Kinerja Auditor: Studi pada KAP di Jakarta. AKTIVA, Vol, 4 No. 1 Oktober 2011 : 1-26.

Rohman, Fatchur. 2008. Pengaruh Komitmen Organisasional dan Komitmen Profesional Terhadap Kepuasan Kerja Auditor Dengan Motivasi Sebagai Variabel Intervening. Skripsi S1, Fakultas Ekonomi Universitas Islam Sultan Agung Semarang.

Sapariah, Rina Ani. 2011. Pengaruh Good Governance dan Independensi Auditor Terhadap Kinerja Auditor dan Komitmen Organisasi: Survey Pada Kantor Akuntan Publik. Surakarta.

Sukriyah, Ika, Akram, dan Biana Adha Inapty. 2009. Pengaruh Pengalaman Kerja, Independensi, Obyektifitas, Integritas dan Kompetensi Terhadap Kualitas Hasil Pemeriksaan. SNA XII Palembang.

Trisnaningsih, Sri. 2007. Independensi Auditor Dan Komitmen Organisasi Sebagai Mediasi Pengaruh Pemahaman Good Governance, Gaya Kepemimpinan Dan Budaya Organisasi Terhadap Kinerja Auditor. SNA X Makassar.

Wati, Elya, Lismawati, dan Nila Aprilia. 2010. Pengaruh Independensi, 